\title{
RGU ROBERT GORDON
}

\section{OpenAIR@RGU \\ The Open Access Institutional Repository \\ at Robert Gordon University}

\section{http://openair.rgu.ac.uk}

This is an author produced version of a paper published in

$$
\text { Energy (ISSN 0360-5442) }
$$

This version may not include final proof corrections and does not include published layout or pagination.

\section{Citation Details}

Citation for the version of the work held in 'OpenAIR@RGU':

ABU-BAKAR, S. H., MUHAMMAD-SUKI, F., FREIER, D., RAMIREZ-
INIGUEZ, R., MALLICK, T. K., MUNIR, A. B., YASIN, S. H. M.,
MAS'UD, A. A. and YUNUS, N. M., 2015. Optimisation of the
performance of a novel rotationally asymmetrical optical
concentrator design for building integrated photovoltaic system.
Available from OpenAIR@RGU. [online]. Available from:
http://openair.rgu.ac.uk

Citation for the publisher's version:

ABU-BAKAR, S. H., MUHAMMAD-SUKI, F., FREIER, D., RAMIREZINIGUEZ, R., MALLICK, T. K., MUNIR, A. B., YASIN, S. H. M., MAS'UD, A. A. and YUNUS, N. M., 2015. Optimisation of the performance of a novel rotationally asymmetrical optical concentrator design for building integrated photovoltaic system. Energy, Vol. 90 (1), pp. 1033-1045.

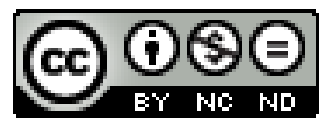

This work is licensed under a Creative Commons Attribution - NonCommercial - No-Derivatives 4.0 International Licence

Copyright

Items in 'OpenAIR@RGU', Robert Gordon University Open Access Institutional Repository, are protected by copyright and intellectual property law. If you believe that any material held in 'OpenAIR@RGU' infringes copyright, please contact openair-help@rgu.ac.uk with details. The item will be removed from the repository while the claim is investigated. 
(C) 2015. This manuscript version is made available under the CC-BYNC-ND 4.0 license http://creativecommons.org/licenses/by-nc-nd/4.0/

http://dx.doi.org/10.1016/j.energy.2015.07.133 


\section{Optimisation of the Performance of a Novel Rotationally Asymmetrical}

\section{Optical Concentrator Design for Building Integrated Photovoltaic System}

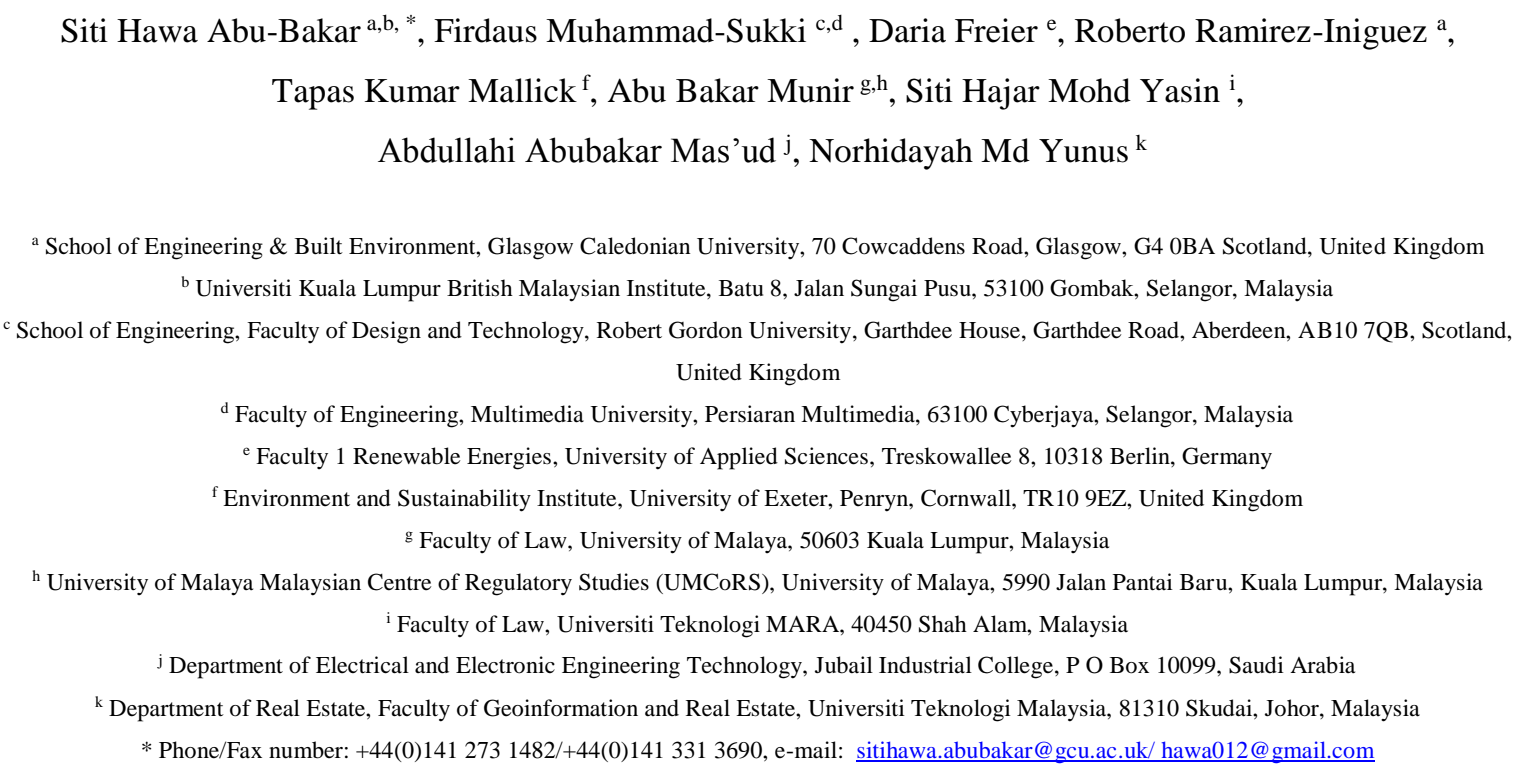

Abstract: Solar energy is one of the renewable energy sources that has shown promising potential in addressing the world's energy needs, particularly via the solar photovoltaic (PV) technology. However, the high cost of installation is still being considered as the main obstacle to the widespread adoption of solar PV system. The use of solar concentrators is one of the solutions that could help to produce lower cost solar PV systems. One of the existing concentrator designs is known as the rotationally asymmetrical dielectric totally internally reflecting concentrator (RADTIRC) which was developed in Glasgow Caledonian University (GCU) since 2010. This paper aims at optimising the existing RADTIRC prototype by increasing its electrical output whilst keeping the cost of the system at minimum. This is achieved by adopting a better material and a different technique to fabricate the concentrator. The optimised RADTIRC prototype was fabricated from polymethyl-methacrylate (PMMA) using injection moulding. It was found that the optimised RADTIRC-PV prototype generated an opto-electronic gain of 4.48 when compared with the bare cell under standard test conditions (STC). A comparison with the old prototype showed that the optimised RADTIRC-PV prototype increased the short circuit current by $13.57 \%$ under STC.

Keywords: solar photovoltaic; solar concentrator; rotationally asymmetrical concentrator; rotationally asymmetrical dielectric totally internally reflecting concentrator. 


\section{Introduction}

Energy is essential in our daily life. It is needed not only to meet the social and economic development, but also to improve human welfare and health [1]. According to a recent report by the Energy Information Administration (EIA), the world's annual energy consumption is projected to rise to $812 \mathrm{EJ}$ in 2035, more than twice the energy needed in 1990. However, the rising trend of energy consumption contributes directly to increasing greenhouse gas (GHG) emissions - mainly due to the fact that the largest proportion of the energy supply comes from fossil fuels. The GHG emission traps the heat from being reflected back into the outer space and causes earth's temperature to rise which subsequently results in climate change [2]. Countries around world experience extreme weather conditions (e.g. massive flood [3], severe draughts [4] and extreme rain, snow and hail [5]) as consequences of climate change. These events also trigger major changes on energy use in the built environment [6-8]. To mitigate the GHG emissions while satisfying the world's energy needs, one of the options suggested by the Intergovernmental Panel on Climate Change (IPCC) is the deployment of renewable energy (RE) technologies [1].

According to the IPCC, solar has 'the largest technical potential' when compared with other renewables [2]. To harness solar energy, one of the technologies that has been utilised is the solar photovoltaic (PV) system, which converts the sun energy directly into electricity. It was calculated theoretically by Luque and Hegedus [9] that a solar PV system with only $10 \%$ conversion efficiency installed in $0.4 \%$ of the earth's land area could meet all the energy demand (electricity, heat and transportation) in 2010.

To date, it is estimated that the solar PV installation reached a cumulative capacity of $177 \mathrm{GW}$ worldwide [10]. The growing interest in developing zero energy buildings (ZEBs) $[11,12]$ as well as the introduction of feed-in tariff scheme [13-16] catalysed the uptake of solar PV installation in many countries. However, although there has been an oversupply and declining prices of PV modules, the overall installation cost of a PV system in many countries is still considered very expensive. It is estimated that the usage of PV material which contributes to $73 \%$ [17] of the cost of the PV module, i.e. PV material contributes to $32.85 \%$ of the overall installation cost. To achieve this reduction in PV material without compromising the PV module's output performance, a number of researchers have suggested to incorporate a solar concentrator design in the PV module [18-22].

A concentrator works by focusing the solar energy from a large entrance aperture area to a smaller exit aperture area to which a solar PV cell is attached [22]. By adopting this 
approach, it is possible to minimise the usage of PV material significantly while maintaining the same electrical output. The concentrator can be fabricated using inexpensive materials such as plastic or mirrors, which offsets the cost of the displaced PV material [22]. Specifically for building integration, the PV technology that includes a low gain concentrator (gains $<10 \mathrm{x}$ ) in the design is desirable since it has a wider half-acceptance angle to maximise the collection of sunlight throughout the day as well as to cater for variations of sun path throughout the year, hence eliminating the need for any mechanical sun tracking system. This low gain concentrator-PV is commonly known as low-concentration photovoltaics (LCPV) system.

In the last few years, various LCPV designs have been demonstrated by many researchers. Sarmah et al. investigated the performance of a linear dielectric asymmetrical compound parabolic concentrator (ACPC) design and evaluated its performance indoor [23] and outdoor [24]. They concluded that the design achieved a maximum power ratio of 2.27 when compared with a non-concentrating panel and could reduce the cost per unit power by 20\% [23]. Mallick and Eames [25] also demonstrated another variation of the dielectric ACPC achieving a power ratio of 2.01 and a theoretical cost reduction of $40 \%$ when compared with a non-concentrating module. Guiqiang et al. investigated a novel air-gap-lenswalled compound parabolic concentrator (ALCPC) [26-29]. From the experiment, they demonstrated that the ALCPC generated comparable maximum output power when compared with a common mirror CPC but at the same time provided superior half-acceptance angle than a common mirror CPC - allowing the ALCPC to generate more electricity in a year [26]. They also claimed that the ALCPC design could reduce the overall cost significantly since it utilises between $20 \%$ and $25 \%$ of the dielectric material used by Mallick and Eames [25]. Muhammad-Sukki et al. [30-36] simulated the performance of an extrusion of a symmetrical dielectric totally internally reflecting concentrator (DTIRC) based on the maximum concentration method (MCM). The design could achieve a maximum optical concentration gain of 4.08 when compared with a bare cell [33] and could reduce the overall installation cost by $41 \%[34,35]$.

Ramirez-Iniguez et al. [37] developed a novel rotationally asymmetrical dielectric totally internally reflecting concentrator (RADTIRC) with the aim of providing additional gain on two different axis, which increases the electrical output and reducing the usage of PV material, which subsequently reduces the overall cost of the system [38]. This design was created from the DTIRC based on the phase conserving method (PCM). One specific design was fabricated and evaluated both indoors and outdoors [39]. The computer-aided design 
(CAD) has a geometrical concentration gain of 4.9069, two half-acceptance angles of $30^{\circ}$ along the north-south axis (z-axis) and $40^{\circ}$ along the east-west axis (x-axis) respectively, a total height of $3 \mathrm{~cm}$ and a square exit aperture with sides of $1 \mathrm{~cm}$ (see Figure 1) [39]. The concentrator was created using a silicon mould and the material used to produce the concentrator was a type of acrylic known as '6091' (supplied from Renishaw Plc.) with a refractive index of 1.515 [39]. It was found that the design could achieve a maximum optoelectronic gain of 4.2 when compared with a bare PV cell [39].

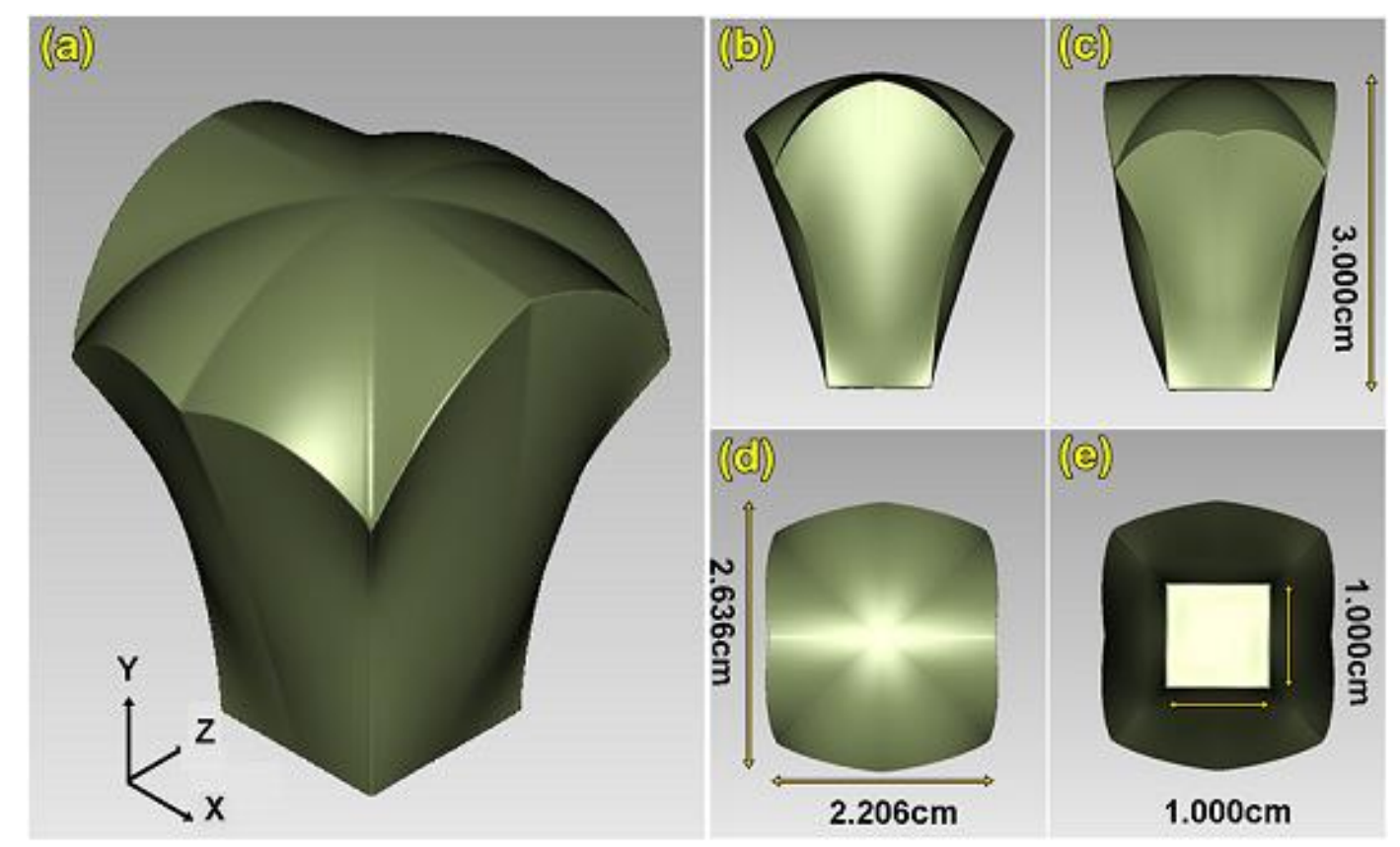

Figure 1: Prototype RADTIRC dimensions [38].

Although the first prototype yielded good results, two problems were identified: (i) the dimensions of the concentrator were smaller than the design specifications due to the usage of a silicon mould (see Figure 2), and (ii) the material used in the prototype suffered from discoloration and photo degradation with time (from clear to yellowish colour as illustrated in Figure 3), which reduced its maximum power performance by $7.84 \%$ after 2 years (from $72.03 \mathrm{~mW}$ to $66.38 \mathrm{~mW}$ ), as presented in Figure 4. This paper aims to further optimise this RADTIRC prototype. In particular interest will be to adopt a better material and a different fabrication technique. 

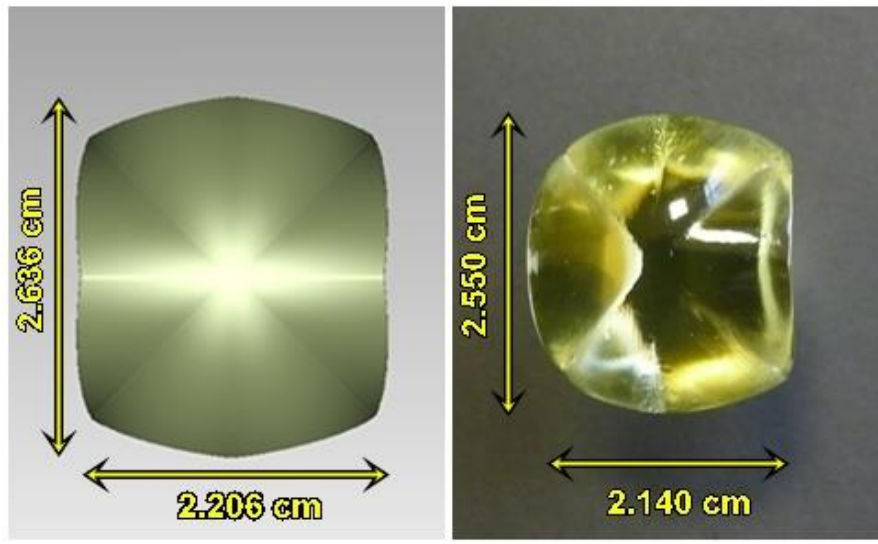

Figure 2: The dimension comparison of the CAD file (left) and the actual one fabricated using a silicon mould (right).
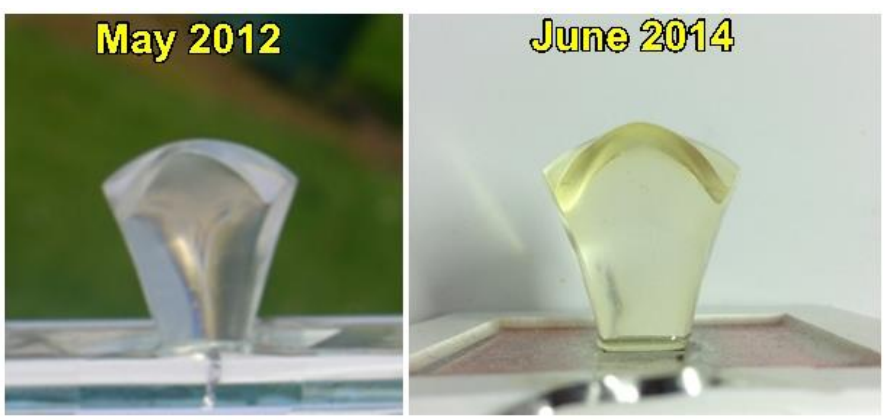

Figure 3: The first prototype of RADTIRC fabricated using the 6091 resin which suffered from discoloration and photo degradation after 2 years.

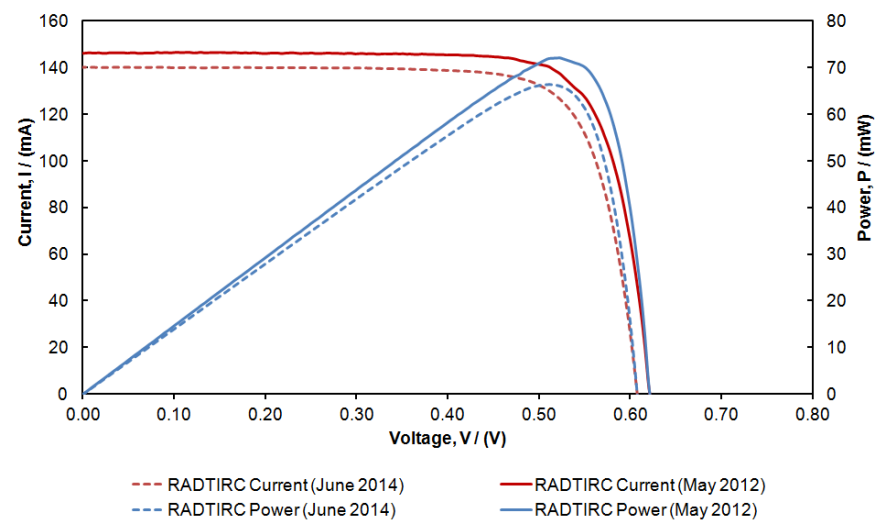

Figure 4: The comparison of the RADTIRC-PV structure performance for experiments carried out in 2012 and 2014.

Sections 2 and 3 explain about the material and the fabrication technique chosen to fabricate the optimised prototype respectively. Section 4 discusses in detail the assembly process of the optimised RADTIRC-PV structure. Afterwards, Section 5 presents the 
simulations that were carried out to evaluate the performance of the RADTIRC-PV structure. Subsequently, the experimental setup is laid out in Section 6 before presenting the experimental results in Section 7. Finally the conclusions and future works are presented at the end of the paper.

\section{Choosing the material for the optical concentrator}

There are a number of factors that need to be taken into account when choosing the material for any LCPV system. For any concentrator that is fabricated from a dielectric material, the requirement include [18]:

i. The cost of the material must be cheaper that the cost of the displaced PV material. This ensures that the design can reduce the overall cost of installation;

ii. The dielectric material must have excellent/high transmission and low absorption to ensure that all the light is transmitted to the solar cell. This will also reduce the optical loss in the system.

iii. The dielectric material must have a higher mechanical strength than the encapsulation material to ensure that the concentrator can maintain its geometrical features.

iv. The material must be durable - it must last long enough to match the longevity of the solar cell attached to it, which normally has a manufacturer guarantee of approximately 25 years. For this reason, it should have a high resistance to photo degradation.

v. The weight of the material must be considered carefully to ensure that the weight of CPV panel is comparable to the traditional panel which will ease the installation;

As indicated by Sarmah [18], many researchers in CPV systems have opted for a variety of dielectric materials to fabricate their concentrator designs. These include polycarbonate and polystyrene. He concluded that despite having excellent optical properties and mechanical strength, these materials have very poor resistance when exposed to prolonged outdoor conditions and suffered from photo degradation, unlike polymethylmethacrylate (PMMA) and polyurethane [18].

PMMA has excellent transmittance property (minimum 92\%) [40] and a high resistance to photo degradation [41,42]. Rainhart and Schimmel [41] presented the performance of an acrylic PMMA panel installed in Sandia Laboratories in Albuquerque, New Mexico for 17 years and 8 months. They indicated that 'the decrease in optical 
transmission was surprisingly low', a reduction of only 3\%, making it a strong candidate as a material for LCPV. On top of that, PMMA is 'adaptable to many fabrication techniques' [41] including extrusion, diamond turning and moulding. Because of these factors, PMMA has been chosen for the fabrication of many LCPV designs, such as Fresnel lenses [43-45], CPCs [26,28,29,46], ACPCs [25,47], and luminescent solar concentrators (LSCs) [48-51]. Based on these facts, it is proposed that the material used for the optimised RADTIRC was PMMA.

\section{Choosing the fabrication technique}

To produce a solar concentrator, there are various fabrication techniques available to date. These include 3D printing, silicon moulding, injecting moulding and single diamond turning. It has been indicated earlier that the old prototype (studied by Muhammad-Sukki et.al [38,39]) was fabricated from a silicon mould and that this prototype shrinked. Therefore this technique is not considered in this paper. As for 3D printing, the machines can only utilise specific materials predefined by the printer manufacturers and PMMA is not listed as a compatible material to be used for 3D printing [52]. Therefore, this fabrication technique is not discussed here either.

\subsection{Injection moulding}

Injection moulding is a fabrication technique in which a material is injected into the mould to produce the part(s) needed, and is considered as one of the best techniques in producing plastic type parts [53], i.e. thermoplastic and thermoset plastic [54]. The former can be heated and shaped many times (e.g. PMMA, polypropylene and polystyrene) while the latter can only be heated and shaped once (e.g. epoxy resin and polyester resin) [54]. This technique was employed to fabricate the ACPC design by Mallick and Eames [25] and the Fresnel lenses by Zhuang and $\mathrm{Yu}$ [55] and Languy et al. [56].

Figure 5 helps to explain the general process of injection moulding [57]. First, the granulated plastic material is poured into the 'hopper' and is fed into the barrel. The presence of heater bands around the outside of the barrel increases the temperature of the barrel to melt the plastic materials according to the desired specifications. The melted plastic is then being pushed along the barrel by the rotating screw into the mould tool and pressure is applied to ensure that the melted materials filled all mould cavities. Afterwards, the melted material is 
allowed to cool and solidify accordingly. The final moulded part is then taken out by removing the moving platen from the fixed platen.

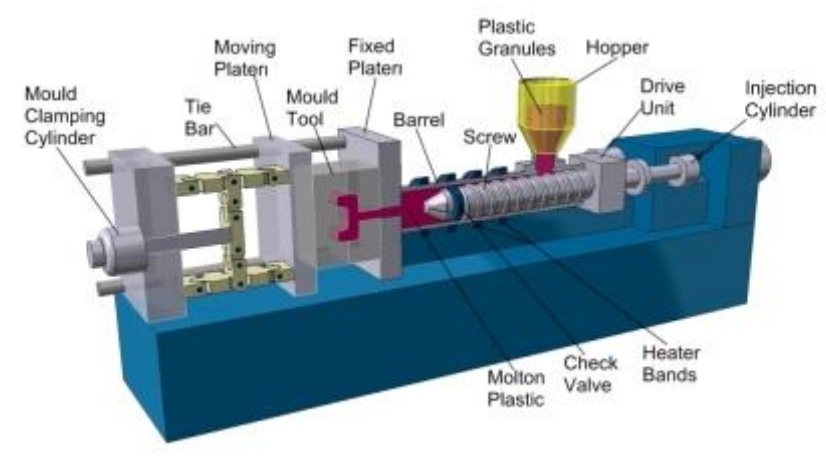

Figure 5: The injection moulding process [57].

The injection moulding technique offers several advantages compared with other plastic moulding techniques. Nanoplas Inc. has indicated some of these advantages which include [58]:

i. the ability to produced detailed features and complex geometries since the machine can hold high pressure, unlike other techniques e.g. the silicon moulding;

ii. producing the part(s) in a more efficient manner. Each design can be tailored according to the customer's needs and is pre-programmed into the machine. This helps to expedite the moulding process, allowing more parts to be completed or manufactured in a single mould (i.e. save the cost of producing a different mould for a different part/design). In short, this technique offers more cost effective and better mass production capabilities compared to other techniques.

iii. producing a stronger part due to the capability of using fillers. During the injection moulding process, these fillers can be added into the mould which enhances the strength of the moulded part. This could not be done with 3D printing or with a single point diamond turning process.

iv. the ability to utilise multiple plastic materials at the same time by utilising the built-in co-injection moulding programme.

v. reducing the manufacturing cost since the whole process is carried out by a preprogrammed machine which effective reduces the labour cost. 
Despite these advantages, it has one main disadvantage, which is the high initial tooling cost [59]. If the volume of production is minimal, it is not cost effective to use this manufacturing technique. The high initial cost can be 'ignored' if the part is intended for mass production [25]. The British Plastic Federation (BPF) shows that for a typical component ${ }^{1}$ fabricated from an injection moulding technique, the unit production cost drops from $£ 1,000$ to around $£ 1$ per unit if the number of production increases from 1,000 to $1,000,000$ units [53].

\subsection{Single point diamond turning}

The single point diamond turning (SPDT) is a fabrication process in which the part is cut from a block of material (known as 'blank') using a single-crystal diamond-cutting tool [60]. The diamond tip cuts the surfaces of the part very accurately down to $1 \mu \mathrm{m}$ in size and at $1 \mathrm{~nm}$ in roughness [61]. This allows the final product to have a 'very good optical surface' [60]. This technique can be utilised to produce any desired part from various materials, including metal, crystal and plastic [60,61]. Some of the examples of concentrators fabricated using this technique include the CPC by Karp and Ford [62], the Fresnel lens by Allsop et al. [63] and the freeform concentrator by Fang et al. [64].

The steps to produce any part by using the SPDT process are as follow [60]: (i) the 'blank' is mounted on a specified fixture in the pre-programmed diamond turning machine; (ii) the appropriate diamond tool is selected depending on the material and the shape of the concentrator and subsequently mounted on the machine; (iii) the optical surface of the blank is machined into the desired concentrator shape, and (iv) the machined concentrator is cleaned to remove the cutting oils or solvents.

Rhorer and Evans [60] have listed some of the advantages of using the SPDT technique over other fabrication methods. These include: (i) the capability to produce good optical surfaces especially at the edges of the optical element; (ii) the ability to produce parts even from soft ductile materials, and (iii) the ease with which any free form optical element can be produced whether it is symmetrical or asymmetrical.

However, there are also some disadvantages of using this technique. The SPDT method has a high rejection rate mainly due to demanding requirement on accuracy and

\footnotetext{
${ }^{1}$ It is not clear what 'component' was analysed by the BPF. However, the information is useful to demonstrate the reduction in unit cost when the component is produced in high volume.
} 
surface finish [61]. This method is also not suitable for mass production because of time and cost issues, i.e. it is time consuming to produce one part and the cost per unit is very expensive (between 100 and 1,000 times more expensive than injection moulding at high volume) [61].

Taking into account the pros and cons from both methods, and based on the advise from UK Optical Plastic Ltd. [65], it was decided that the optimised design were fabricated using the injection moulding technique. The main determining factor is the cost of production, i.e. it is intended that a larger CPV system that incorporates an array of the RADTIRC design to be fabricated and tested indoor and outdoor afterwards. In terms of performance, a detailed study by Huang [66] concluded that the injection moulding process is capable of producing an optical concentrator with high precision provided that accurate mould compensation and precise process control are in place.

\section{Assembly process of the RADTIRC-PV device}

\subsection{Design of the RADTIRC}

The optimised prototype of the RADTIRC was fabricated by UK Optical Plastic Ltd using injection moulding [65]. The company utilised an injection moulding machine known as BOY 35M [65]. The material chosen for the concentrators is a variation of PMMA known as Altuglas ${ }^{\circledR}$ V825T, which has a refractive index of $1.49^{2}$ [67]. The concentrator has a total height of $3 \mathrm{~cm}$, a square exit aperture of $1 \mathrm{~cm}$ by $1 \mathrm{~cm}$, a geometrical concentration gain of 4.9069 , an index of refraction of 1.5, and two 'design' half-acceptance angles of $\pm 40^{\circ}$ along the $\mathrm{x}$-axis and $\pm 30^{\circ}$ along the $\mathrm{z}$-axis to cater for variation of sun path during the day and throughout the year. This optimised design follows the same RADTIRC specification of the one fabricated and tested by Muhammad-Sukki et al. [38,39]. The moulded RADTIRC was polished to an 'acceptable' degree and the final design is presented in Figure 6.

\footnotetext{
${ }^{2}$ The index of refraction of the PMMA material is 1.49 , which almost the same as the index of refraction of the RADTIRC design, which is 1.5 .
} 


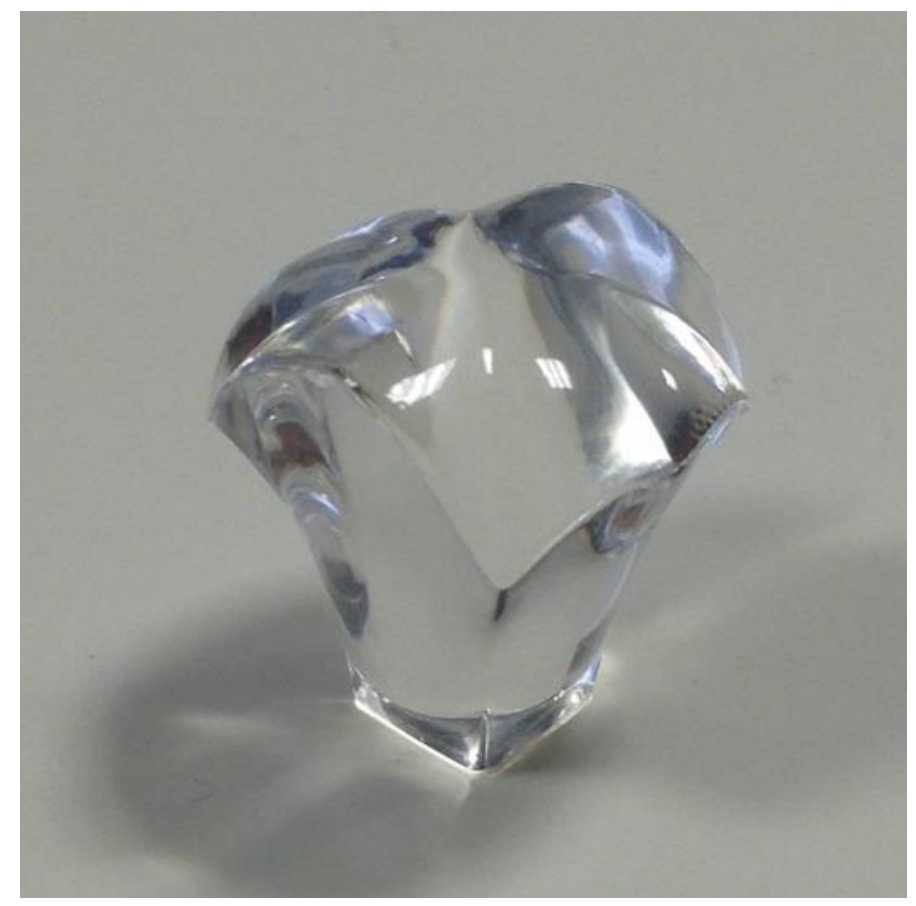

Figure 6: The final form of the optimised RADTIRC prototype.

It was important to measure the dimensions of the optimised design to check that shrinkage had not occurred. The entrance aperture of the optimised RADTIRC was measured using a Vernier gauge, and the measurements were compared with the CAD design (the desired design) and the old prototype and the results are indicated in Table 1. The negative reading indicates that the measured dimension is smaller than the desired dimension. The measurement along the y-axis of the optimised design is much closer to the desired measurement, with a deviation of only $-2.50 \%$, unlike the old prototype which showed a deviation of $-3.26 \%$. The possible reason of this small deviation is the over polishing on removing the injection points from the moulded concentrator. However, the reading along the $\mathrm{x}$-axis of the optimised design is slightly larger than the desired measurement, approximately by $3.35 \%$. This is contributed by the 'flash' - a very thin layer of excess material which typically appears between two surfaces of the mould. In conclusion, the dimension of the optimised design is much closer to the desired CAD design, and approximate area deviation of $0.8 \%$, unlike the old prototype that has a deviation of $-6.2 \%$. 
Table 1: Measurements of the entrance apertures of the RADTIRCs.

\begin{tabular}{|c|c|c|c|c|c|}
\hline \multirow{2}{*}{ Description } & \multirow{2}{*}{$\begin{array}{l}\text { CAD } \\
\text { design }\end{array}$} & \multicolumn{2}{|c|}{ Old prototype } & \multicolumn{2}{|c|}{ Optimised prototype } \\
\hline & & Measured & $\begin{array}{l}\text { Percentage of } \\
\text { change with } \\
\text { respect to the } \\
\text { CAD design } \\
(\%)\end{array}$ & Measured & $\begin{array}{l}\text { Percentage of } \\
\text { change with } \\
\text { respect to the } \\
\text { CAD design } \\
(\%)\end{array}$ \\
\hline Along $\mathrm{x}$-axis & 2.206 & 2.14 & $-2.99 \%$ & 2.28 & $3.35 \%$ \\
\hline Along y-axis & 2.636 & 2.55 & $-3.26 \%$ & 2.57 & $-2.50 \%$ \\
\hline
\end{tabular}

321

322

323

324

325

326

327

328

329

330

331

332

333

334

335

\subsection{Solar cell}

The solar cells used for the test were supplied by Solar Capture Technologies Ltd, UK. The monocrystalline silicon wafer has Laser Grooved Buried Contact (LGBC) and is suitable for LCPV applications (maximum solar concentration ratio of up to 10x) [68]. To produce suitable cells for the concentrators, a large silicon wafer with a size of $125 \mathrm{~mm} \times 125$ $\mathrm{mm}$ is patterned and laser-grooved to produced bus bars and fingers. Each bus bar has a width of $1 \mathrm{~mm}$ while each finger has a width of $0.714 \mathrm{~mm}$. This wafer was then cut into smaller cells with each cell has dimensions of $1 \mathrm{x} 1 \mathrm{~cm}$. The process of cutting the silicon wafer into smaller cells introduced some errors in terms of the final sizes of the cells, as presented in Figure 7, with a width deviation of $13 \%$. When the cell is permanently bound to the exit aperture of the concentrator, this deviation introduces some error in the experiment results. If the size of the active area of the solar cell is bigger than the exit aperture area of the concentrator, a higher opto-electronic gain is obtained. Meanwhile, if the size of the active area of the cell is smaller than the exit aperture of the concentrator, not all the concentrated rays reach the cell resulting in a lower opto-electronic gain. 


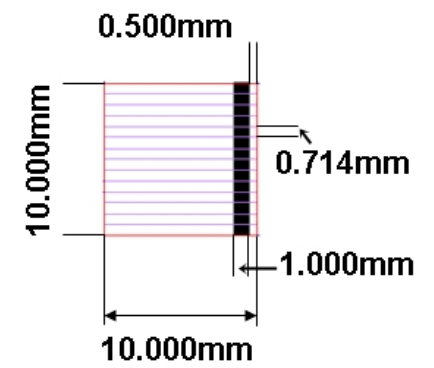

a)

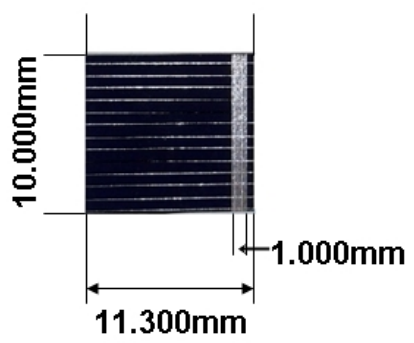

b)

Figure 7: The $1 \mathrm{~cm}^{2}$ solar cell provided by the Solar Capture Technologies, showing (a) the schematic of the cell, and (b) the measured dimension of the cell.

\subsection{Assembly process}

For the initial test, only one optimised RADTIRC-PV device was constructed. This concentrator-PV cell structure was compared with a bare cell. First, two solar cells were tabbed with a flat lead free wire having dimensions of $0.1 \mathrm{~mm}$ thickness and $1 \mathrm{~mm}$ width. The tabbing wire was soldered using a soldering iron with a power of $81 \mathrm{~W}$ and at a working temperature of $350^{\circ} \mathrm{C}$. The soldering process was carried out over a short period of time to avoid damaging the solar cells. Furthermore, the tabbing wire was soldered on the edge of the cells to maximise the active area of the cell. The tabbed cells were then glued on two separate glass substrates (70 mm x $70 \mathrm{~mm} \times 40 \mathrm{~mm})$.

To permanently mount the RADTIRC on one of the solar cells, a silicon elastomer Sylgard-184® from Dow Corning was chosen as the binding material. This material also acts as an encapsulation material for the solar cell. It has excellent transmittance (94.4\%) [69] and can be cured using a simple process $[23,38]$. The Sylgard-184® was prepared by mixing the supplied base and curing agent in a 10:1 weight ratio in a small beaker. The mixture is then placed in a vacuum chamber for 15 minutes to eliminate air bubbles. A Dow Corning Primer 92-023 was applied on the solar cells for a better adhesion between the Sylgard and the cell. Once the Sylgard was free from air bubbles, the mixture was poured on top of the solar cell. Afterwards, the RADTIRC was placed carefully on top of the solar cells and the elastomer was left to cure for 48 hours under room temperature to ensure good binding between the concentrators and the cell. The photograph of the two samples (an RADTIRC-PV device and a bare solar cell) is presented in Figure 8. 


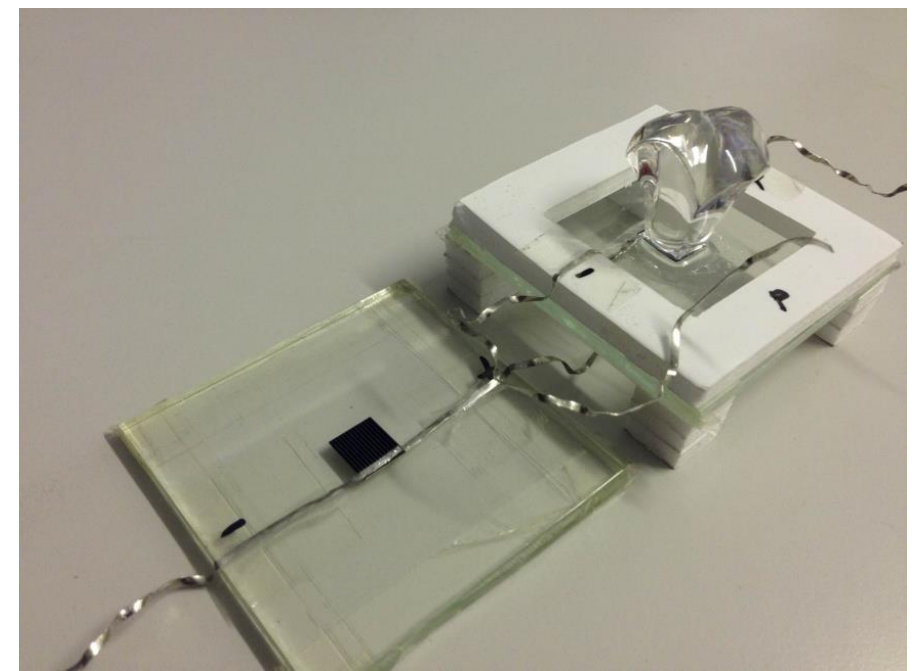

Figure 8: Photograph of an RADTIRC-PV structure and a bare solar cell.

\section{Simulation of the Optical Concentration Gain}

Prior to carrying out the indoor experiments, an optical concentration analysis was carried out to determine theoretically the performance of the optimised RADTIRC-PV structure when exposed to the sun. The optical concentration gain, $C_{\text {opt }}$ is defined as $[70,71]$ :

$$
C_{\text {opt }}=\frac{\beta_{\text {exit }}}{\beta_{\text {entrance }}} \times C_{g}
$$

where $\beta_{\text {exit }}, \beta_{\text {entrance }}$ and $C_{g}$ are the flux (in W) at the exit aperture, the flux (in W) at the entrance aperture and the geometrical concentration gain respectively. The ratio of the flux at the exit aperture to the flux at the entrance aperture is also known as the optical efficiency, $\eta_{\text {opt }}$ of a concentrator [70,71]. In theory, any rays within the acceptance angle of the concentrator will emerge at the exit aperture of the concentrator [70], i.e. the rays entering from the side profile of the concentrator are not being considered in the simulation. The analysis evaluates the gain performance of the concentrator when exposed to rays at different angles of incidence.

First, the 3-D surface coordinates of an RADTIRC are generated from MATLAB ${ }^{\circ}$ in a point cloud format. This file is then imported into GeoMagic ${ }^{\circledR}$ software to produce a CAD model from which an Initial Graphics Exchange Specification (IGES) format file model is obtained, such as the one illustrated in Figure 1. Subsequently, this IGES file is imported into 
an optical system design software called ZEMAX® to conduct the ray tracing analysis. A simulation using any optical system design software such as ZEMAX® is better than using a programming software (i.e. MATLAB $®$ ) because [19]: (i) it gives flexibility in analysing any optical devices; (ii) it can analyse a greater number of incoming rays which results in better resolution of the optical flux distribution; (iii) it shortens the simulation times significantly, and (iv) it provides better result representations at the end of the simulation.

The setup for the ray tracing analysis in ZEMAX® is shown in Figure 9. A square light source is selected to produce one million collimated rays and is configured to produce an incoming power of $1,000 \mathrm{~W}$. The CAD file of the RADTIRC is placed at a distance of 38 $\mathrm{cm}$ from the light source ${ }^{3}$. To calculate the number of rays at the entrance and exit aperture of the RADTIRC, two photo detectors are attached at both ends of the concentrator. The simulation is carried out by first, firing the rays perpendicular to the cell where the number of rays at the entrance and exit apertures are calculated and recorded. This is repeated by increasing the rays' incidence angle by $5^{\circ}$ from horizontal plane until a maximum angle of $60^{\circ}$ is reached.

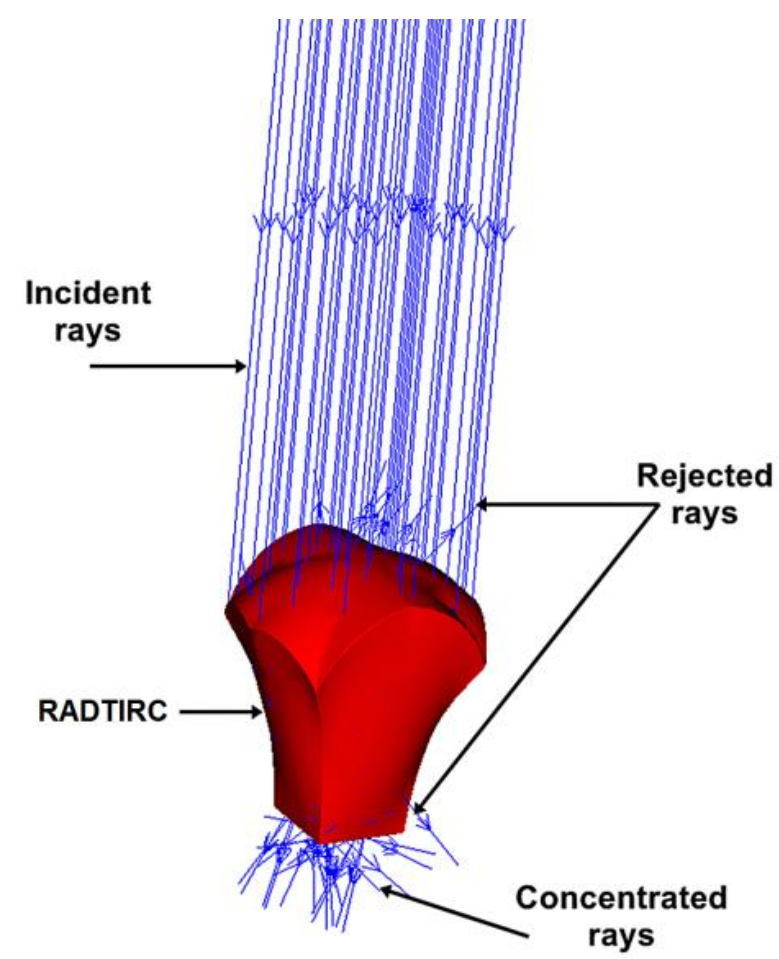

Figure 9: Ray tracing analysis conducted in ZEMAX®.

3 This distance is chosen to match the setup for the indoor experiment, which will be explained later in Section 6. 
Figure 10 shows the optical concentration gain and the optical efficiency variations with angle of incidences of the optimised RADTIRC. From the simulations, it is observed that the concentrator provides a substantial gain within its 'design' half-acceptance angle, achieving a maximum value of 4.62 and an optical efficiency of $94.2 \%$ at normal incidence. The optimised RADTIRC achieved $90 \%$ of its peak optical concentration gain and optical efficiency values when the angle of incidence was $\pm 16^{\circ}$ along both the $\mathrm{x}$ and $\mathrm{z}$-axes. These values reduced to half when the angle of incidence of the rays reached $\pm 36^{\circ}$ and $\pm 30^{\circ}$ along the $\mathrm{x}$ and $\mathrm{z}$-axis respectively. It can also be observed that the optical concentration gain was always greater than 1 (the optical efficiency higher than 10\%) when the angle of incidence was less than and equal to the value of the 'design' half acceptance angle. Beyond the 'design' half-acceptance angle, both parameters reduce to 0 .
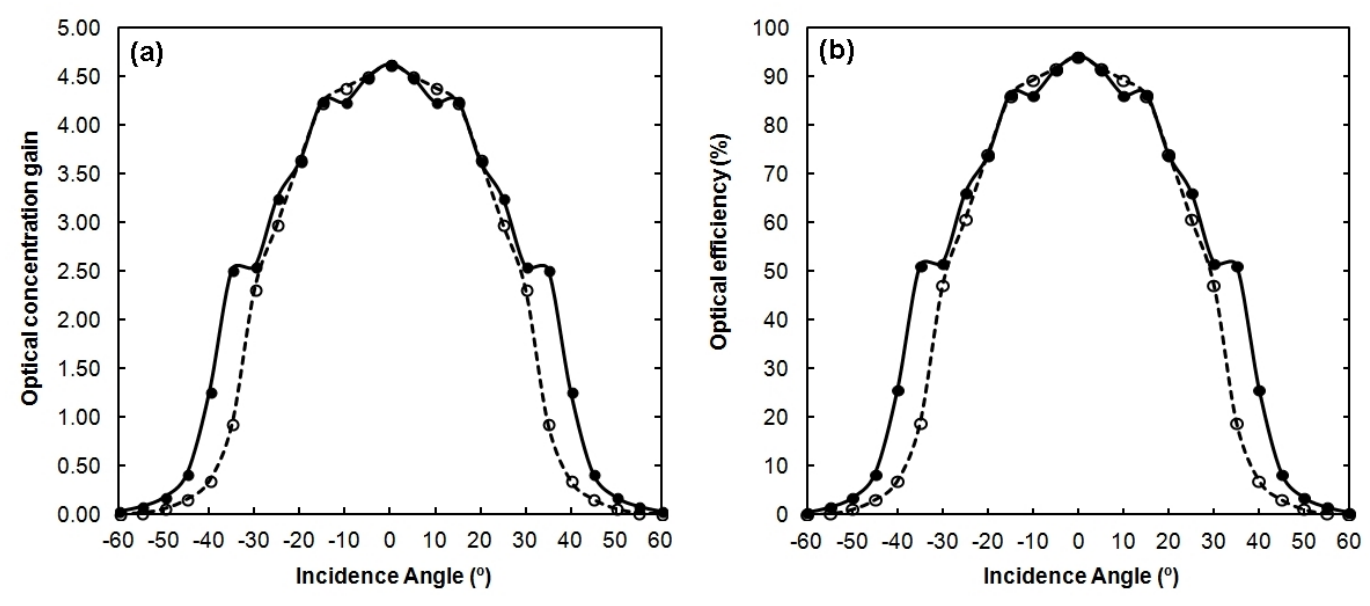

$\rightarrow$ RADTIRC - X - - - RADTIRC - $Z$

$\rightarrow$ RADTIRC - X - - - RADTIRC - Z

Figure 10: The optical concentration gain and the optical efficiency of the optimised RADTIRC.

\section{Experimental setup}

The indoor experimental setup to evaluate the characteristic of the RADTIRC-PV structure is illustrated in Figure 11. A Class AAA solar simulator (Oriel® Sol3A Model 94083A) from Newport Corporation equipped with an air mass (AM) 1.5G filter, was used to reproduce the spectral emission of the sun at the earth surface, providing uniform 
434 illumination with a low marginal error of $\pm 2 \%$ within a $20 \times 20 \mathrm{~cm}$ footprint. A variable slope 435 base was placed approximately $38 \mathrm{~cm}$ beneath the solar simulator's lamp and within the 436 uniform illumination area of the lamp. The variable slope base was used together with a 437 digital tilt meter to accurately measure the tilt angle of the base. A Keithley source meter 438 (Model 2440) with 4-wire connections was utilised here to act as a high accuracy loading 439 circuit $[21,39]$. The source meter was connected to a computer which has already installed the 440 Lab Tracer 2.0 software from National Instruments ${ }^{\circledR}$ to measure the electrical output from 441 the PV cells. The RADTIRC was placed on the variable slope base set at $0^{\circ}$ inclination. 442 Under the standard test conditions (STC), the solar simulator was configured to produce an 443 irradiance of $1,000 \mathrm{~W} / \mathrm{m}^{2}$ and the room temperature was maintained at $25^{\circ} \mathrm{C}$. The irradiance 444 can be varied by turning the integrated variable attenuator at the solar simulator and the 445 irradiance reading can be measured using the PV reference cell system. The door and 446 windows of the room were closed to avoid unwanted air flow and minimise temperature 447 variations and the room windows had blinds to prevent unwanted light from entering the 448 room. In order to obtain the current-voltage and power-voltage curves of the RADTIRC-PV 449 cell (and of the bare cell) and from these characterize the angular variation of the 450 optoelectronic gain of the concentrator, the sample (RADTIRC-PV or the non-concentrating 451 cell) was exposed to the solar simulator light for short periods of time (approximately 5s) 452 using a shutter. This was done to minimise the increase in the solar cell's temperature which 453 would have affected the readings of the open circuit voltage and the fill factor. For each 454 measurement, the short circuit current $\left(I_{s c}\right)$, the open circuit voltage $\left(V_{o c}\right)$, the maximum 455 current $\left(I_{\max }\right)$, the maximum voltage $\left(V_{\max }\right)$, the maximum power $\left(P_{\max }\right)$ and the fill factor $456(F F)$ were determined and recorded. The performance of the RADTIRC-PV structure and the 457 non-concentrating cell were evaluated for these cases: (i) under STC at $0^{\circ}$ inclination; (ii) 458 under STC at different angles of incidence between $-60^{\circ}$ and $60^{\circ}$, and (iii) under various 459 levels of solar radiation at $0^{\circ}$ inclination. 


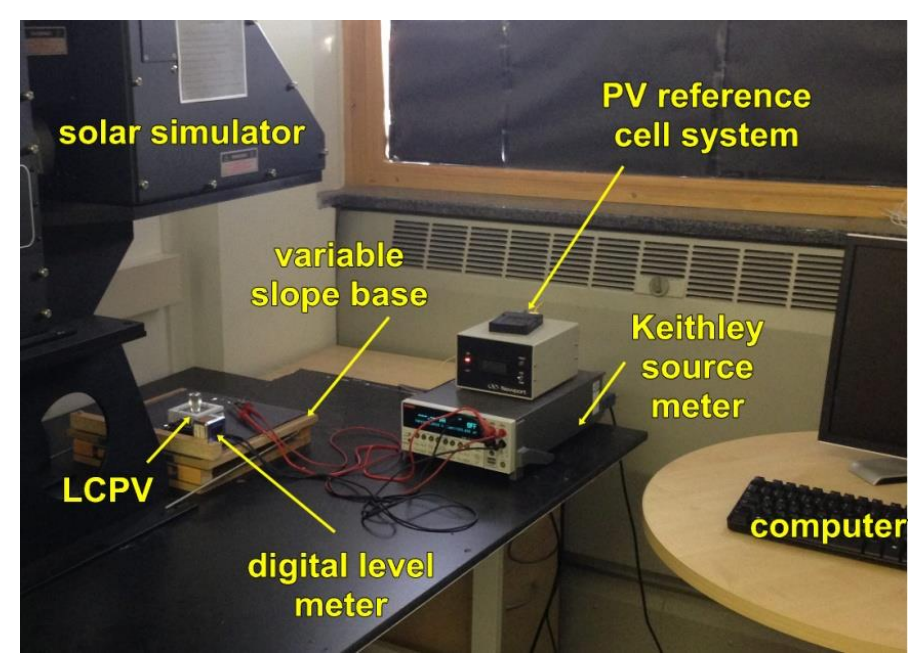

Figure 11: Indoor experimental setup.

\section{Indoor experimental results}

\subsection{Characteristics of the optimised RADTIRC-PV structure under STC at $0^{\circ}$ inclination}

Figure 12 shows the current-voltage (I-V) and the power-voltage (P-V) characteristics of the RADTIRC-PV structure under the STC. From Figure 12, the short circuit current of the bare cell was recorded at $35.5 \mathrm{~mA}$. However, the introduction of the RADTIRC in the design increased the short circuit current by a factor of 4.48 when compared with the bare cell, generating $159.0 \mathrm{~mA}$. The maximum power on the other hand increased from $15.4 \mathrm{~mW}$ to $75.9 \mathrm{~mW}$ when the RADTIRC-PV structure was compared with the bare cell, giving a maximum power ratio of 4.93. The experiment showed that the RADTIRC increased the fill factor from $77 \%$ to $78 \%$. In terms of electrical conversion efficiency, the introduction of the optimised RADTIRC increases this value from $15.38 \%$ to $15.45 \%$. When the short circuit current from the optimised RADTIRC-PV design was compared with the old prototype, the short circuit current showed a superior reading, an increase of $13.57 \%$. A similar trend was observed for the maximum power point reading where the optimised RADTIRC design increased the reading to $76 \mathrm{~mW}$ from only $66 \mathrm{~mW}$ generated by the old prototype. 


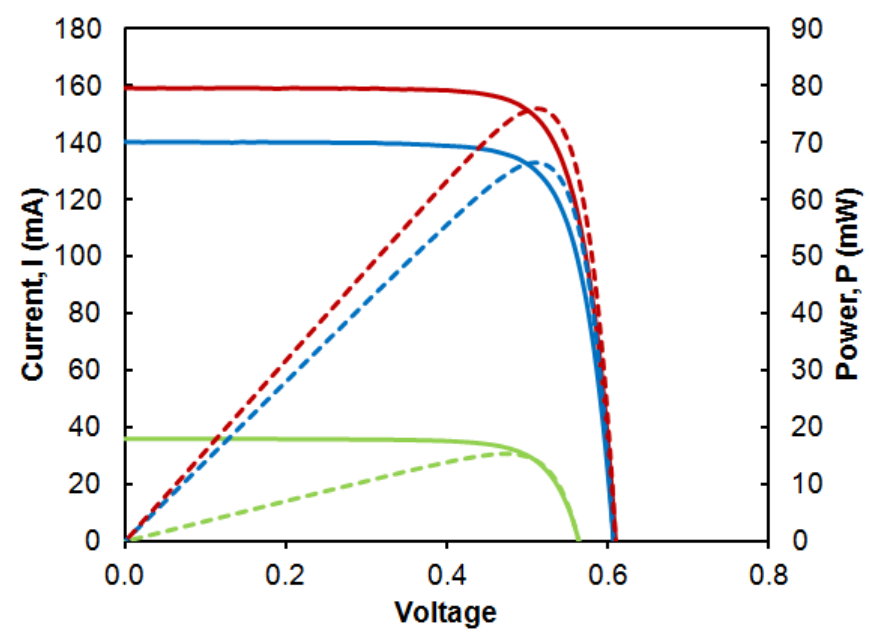

Current - Old Prototype

- Current - Optimised RADTIRC

Current - Bare cell

--- Power- Old Prototype

-- - Power-Optimised RADTIRC

-- Power-Bare cell

Figure 12: The I-V and P-V characteristic of the optimised RADTIRC-PV structure, old prototype, and the bare cell.

\subsection{The angular response of the RADTIRC under STC}

The next part of the experiment consisted in characterising the angular response of the RADTIRC. This experiment evaluates the electrical performance of the system when the sun path varies throughout the day. Instead of tilting the source, the variable slope base was tilted from $0^{\circ}$ to $60^{\circ}$ at increments of $5^{\circ}$, with each tilt angle measured using the digital level meter.

Figure 13 compares the short circuit currents generated by the RADTIRC-PV structure (the optimised design and the old prototype) with the ones generated by the bare cell for angles of incidence within the $\pm 60^{\circ}$ range. In general, the short circuit current showed a decreasing trend when the angle of incidence increased. In Figure 13, it was found that the optimised RADTIRC-PV structure achieved its maximum short circuit current at normal incidence, with the value of 0.159 A recorded. The optimised RADTIRC-PV structure achieved $90 \%$ of its peak short circuit value when the angle of incidence was $\pm 20^{\circ}$ along the $\mathrm{X}$-axis and $\pm 18^{\circ}$ along the $\mathrm{z}$-axis. This value reduced to half when the angle of incidence of the rays reached $\pm 32^{\circ}$ and $\pm 28^{\circ}$ along the $\mathrm{x}$ and $\mathrm{z}$-axis respectively. When the angle of incidence was equal to the 'design' half-acceptance angles, the short circuit current was always higher than the one generated from the bare cell, as illustrated in Figure 13. Beyond 
511

this angle of incidence, the short circuit current continued to decrease eventually reaching 0 A. The results from the experiment also indicate that within the 'design' half-acceptance angles, the optimised RADTIRC-PV structure produces much higher short circuit current than the old prototype, e.g. an increase of $13.57 \%$ at the normal angle of incidence.
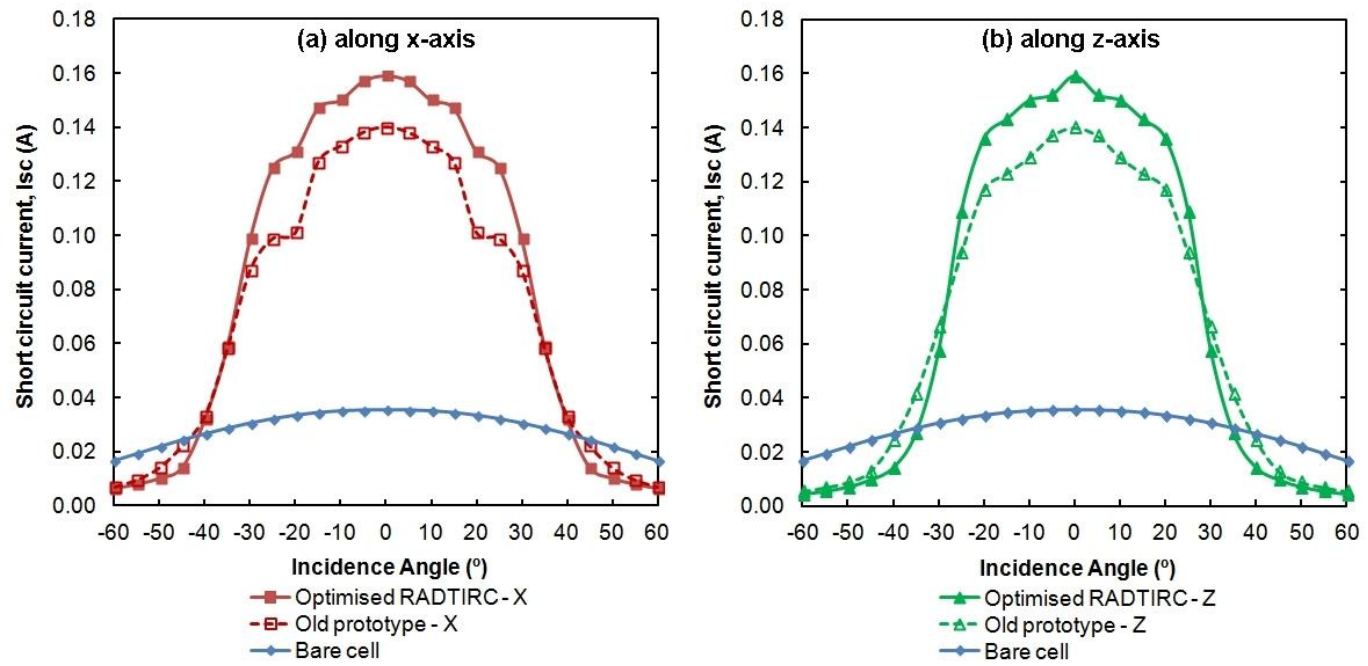

Figure 13: The short circuit currents generated from the optimised RADTIRC-PV structure, the old prototype and the bare cell.

As for the bare cell, although the short circuit current value reduced when the angle of incidence increased, it showed a gradual drop from its peak value. It achieved $50 \%$ of its maximum short circuit current value when the angle of incidence was approximately $\pm 60^{\circ}$. This reduction was contributed mainly due to the cosine effect ${ }^{4}[23,72]$.

There are two ways to investigate the performance of the concentrator. One is by looking at its opto-electronic gain, and the other is by analysing its optical efficiency. The opto-electronic gain measures the ratio of short circuit current produced from a CPV cell to the one generated from a non-concentrating cell $[23,39,73]$. The optical efficiency, on the other hand, is obtained by dividing the opto-electronic gain by the RADTIRC's geometrical concentration ratio value [71,74]. A higher opto-electronic gain is desirable since it translates into a higher short circuit current, while a higher optical efficiency means that a higher

\footnotetext{
4 The cosine angle effect occurs when the surface of a flat solar cell is not normal to the sun radiation (in this case the solar simulator's radiation). The effective value of the sun radiation on the cell reduces by the cosine of the angle between the sun and the cell's normal [72].
} 
527 percentage of the rays that fall on the front surface area are transmitted to the exit aperture of the concentrator. From the opto-electronic gain, the experimental half-acceptance angle of the RADTIRC-PV structure was determined, which is defined as the angle where the gain reached $90 \%$ of its peak value [74]. The opto-electronic gain and the optical efficiency of the optimised RADTIRC-PV structure are presented in Figures 14 and 15 respectively.

533

534

535

536

537

538

539

540

541

542

543

544

545

546

547
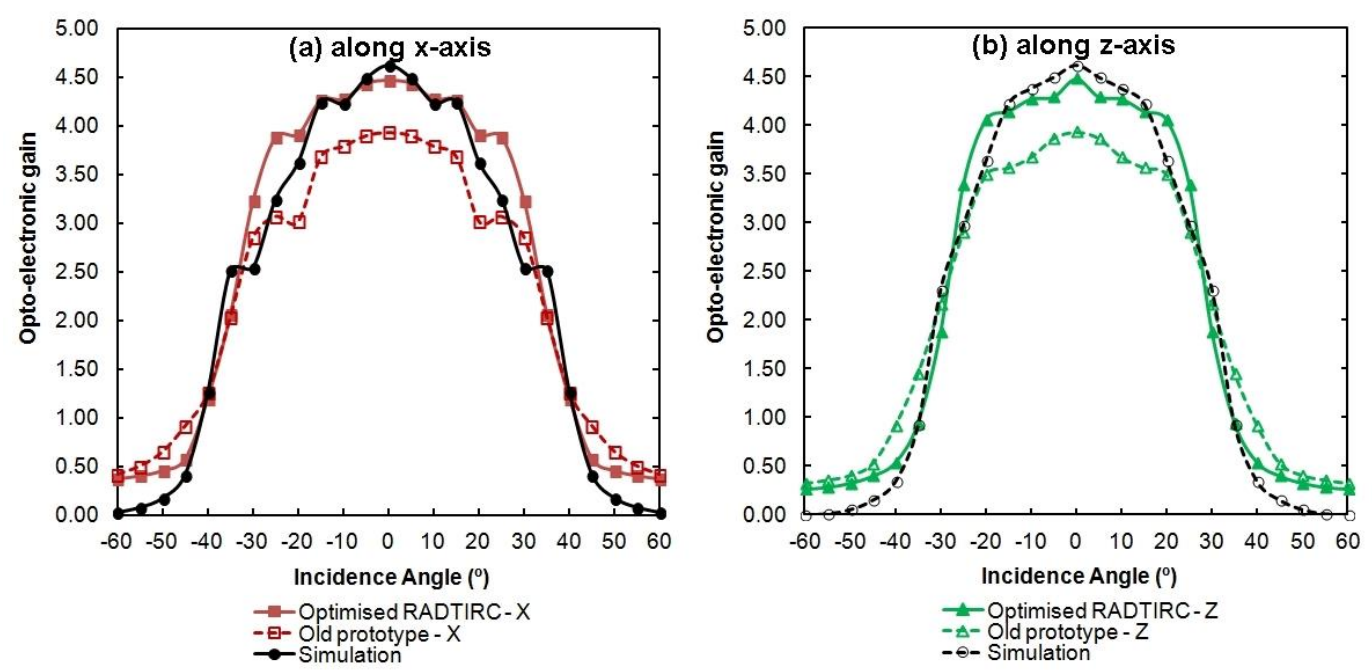

Figure 14: The opto-electronic gain of the optimised RADTIRC-PV structure and the oldprototype.

For the optimised RADTIRC-PV structure, the maximum opto-electronic gain was obtained at normal incidence, with a value of 4.48, unlike the old prototype with only at 3.93. The optimised design achieved $90 \%$ of its peak opto-electronic gain value when the angle of incidence was $\pm 20^{\circ}$ along the $\mathrm{x}$-axis and $\pm 18^{\circ}$ along the $\mathrm{z}$-axis. This value reduced to half when the angle of incidence of the rays reached $\pm 32^{\circ}$ and $\pm 28^{\circ}$ along the $\mathrm{x}$ and $\mathrm{z}$-axis respectively. When the angle of incidence was equal to the 'design' half-acceptance angles, the gain was always higher than 1, as indicated in Figure 14. Outside this incidence angle, the opto-electronic gain dropped gradually to 0 . It can be concluded that within the 'design' halfacceptance angles, the optimised RADTIRC-PV structure produces much higher optoelectronic gain than the old prototype. 

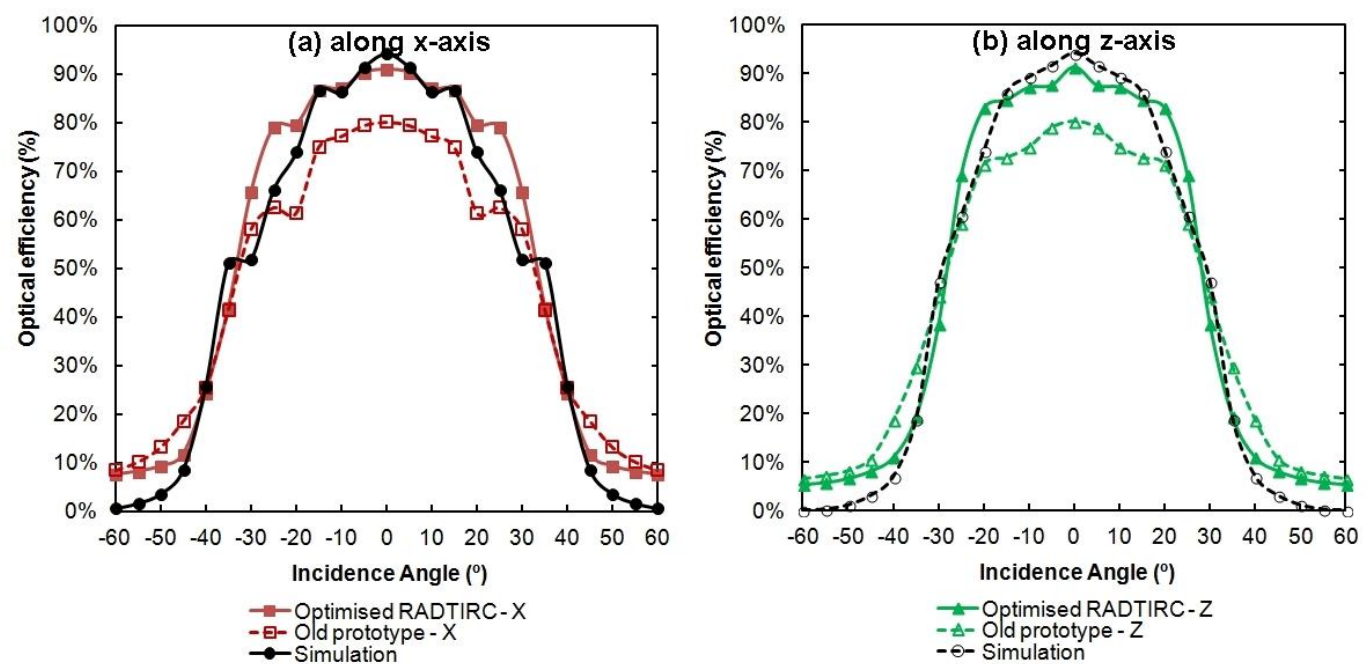

Figure 15: The optical efficiency of the optimised RADTIRC-PV structure and the old prototype.

A similar trend is observed when evaluating the optical efficiency of the RADTIRCPV structures, as illustrated in Figure 15. For the optimised RADTIRC-PV structure, the maximum optical efficiency was obtained at normal incidence, with a value of $91.3 \%$, much higher than the value obtained from the old prototype of only $80.1 \%$. The optimised design achieved $90 \%$ of its peak optical efficiency value when the angle of incidence was $\pm 20^{\circ}$ along the $\mathrm{x}$-axis and $\pm 18^{\circ}$ along the $\mathrm{z}$-axis. This value reduced to half when the angle of incidence of the rays reached $\pm 32^{\circ}$ and $\pm 28^{\circ}$ along the $\mathrm{x}$ and z-axis respectively. Outside this incidence angle, the optical efficiency dropped gradually to 0 . It can be concluded that within the 'design' half-acceptance angles, the optimised RADTIRC-PV structure produces much higher optical efficiency than the old prototype.

The opto-electronic gains and the optical efficiency trend were also compared with the optical results obtained from the simulation using the optical simulation software ZEMAX ${ }^{\circledR}$, discussed previously in Section 5. The results from the experiments show good agreement with the simulation data, with a deviation of $3.5 \%$ at normal incidence. When the angle of incidence is between $\pm 25^{\circ}$ and $\pm 35^{\circ}$, the deviation increases mainly attributed to rays impinging from the side profile of the concentrator being directed to the cell, which are not taken into account during the simulation. This deviation can also be attributed to several other factors, which include: (i) manufacturing errors causing the dimensions of the concentrator to differ from the actual design dimensions, uneven surfaces of the entrance aperture and over polishing on the profile of the side wall, and (ii) assembly errors during the soldering of the 
tabbing wire on the solar cells which reduced the effective area of each cell and misalignment between the solar cell and the exit aperture of the concentrator.

In terms of the variation of the maximum power output with angle of incidence, a similar trend to the one obtained for the short circuit current was observed, as illustrated in Figure 16. The peak value of the maximum power was recorded at $75.9 \mathrm{~mW}$ and $15.4 \mathrm{~mW}$ from the optimised RADTIRC-PV structure and the non-concentrating cell respectively. This translates to a maximum power ratio (power gain) of 4.93. The maximum power generation of the optimised RADTIRC-PV structure reached $50 \%$ of its peak value when the angle of incidence was $\pm 32^{\circ}$ and $\pm 28^{\circ}$ along the $\mathrm{x}$ and z-axes, before gradually dropping to $0 \mathrm{~W}$ when the angle of incidence continued to increase. It can be observed that the optimised RADTIRC-PV structure produced a much higher maximum power output when compared with the old prototype (only $66.4 \mathrm{~mW}$ at peak value), an increment of $14.3 \%$. As for the maximum power from the bare cell, the reduction of the maximum power was more gradual, achieving a $50 \%$ of the peak value when the angle of incidence was closer to $\pm 60^{\circ}$.
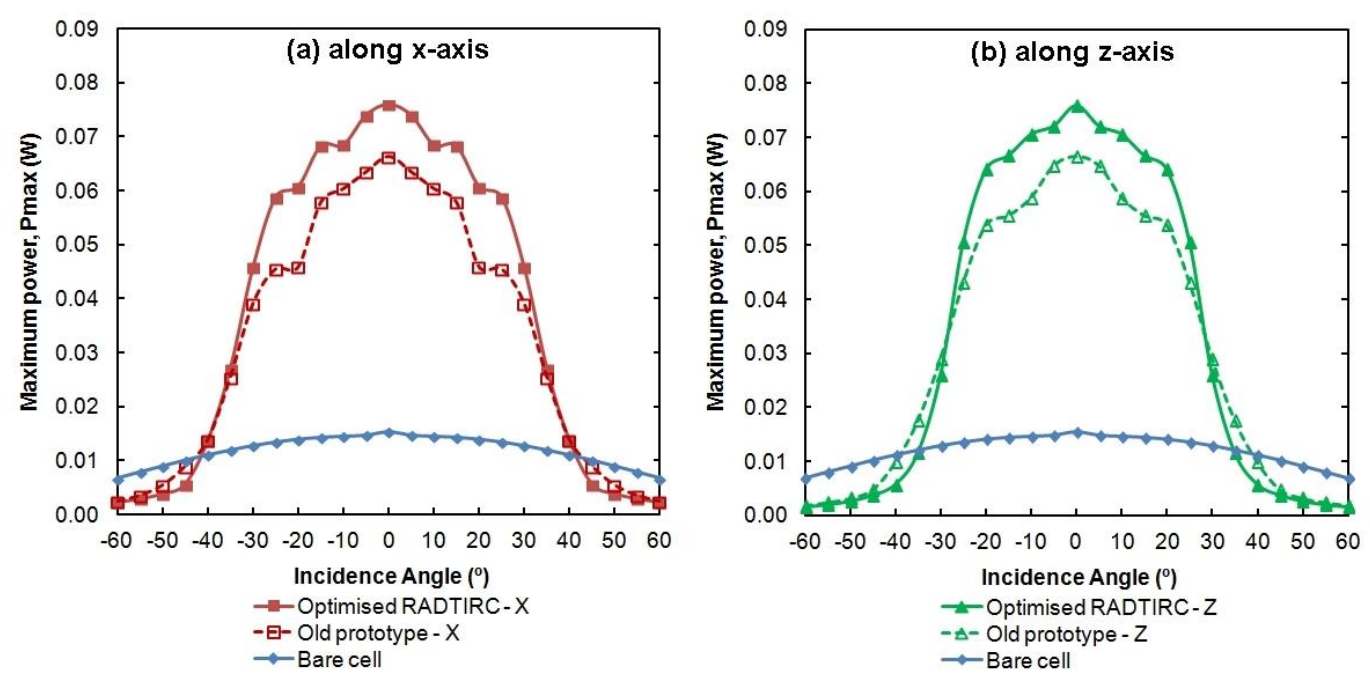

Figure 16: The maximum power generated from the optimised RADTIRC-PV structure and the old-prototype.

\subsection{Variation of solar irradiance at $0^{\circ}$ inclination at $25^{\circ} \mathrm{C}$.}

The experiment was repeated to evaluate the variation of the I-V and P-V characteristics under various levels of solar radiation. This investigation is helpful to evaluate the performance of the RADTIRC-PV structure in locations that have higher or lower 
599

600

601

602

603

604

605

606

607

608

609

610

611

612

613

614

615

616

617

618

619

620

621

average levels of solar irradiance. This was done by turning the variable attenuator control of the solar simulator to change its output from $800 \mathrm{~W} / \mathrm{m}^{2}$ to $1,100 \mathrm{~W} / \mathrm{m}^{2}$, at increments of 100 $\mathrm{W} / \mathrm{m}^{2}$. The results are presented in Figures 17 and 18. Based on the findings from Sections 7.1 and 7.2, it is concluded that the optimised RADTIRC-PV structure performs better than the old prototype. For this reason, this section only compares the performance of the optimised RADTIRC-PV structure with the non-concentrating cell.

When the intensity of the solar simulator increased from $800 \mathrm{~W} / \mathrm{m}^{2}$ to $1,100 \mathrm{~W} / \mathrm{m}^{2}$, the short circuit current from both samples increased from 0.126 A to 0.169 A for the RADTIRC-PV structure and from 0.028 A to 0.039 A for the bare cell. In terms of maximum power, the change in the simulator's intensities caused the reading from the samples to rise from $0.060 \mathrm{~W}$ to $0.082 \mathrm{~W}$ and from $0.012 \mathrm{~W}$ to $0.017 \mathrm{~W}$ for the RADTIRC-PV structure and the bare cell respectively. In general, the RADTIRC-PV structure produces a higher short circuit current and a higher maximum power when exposed to higher level of solar radiation, as expected, which is more desirable by the consumers when they want to reap higher financial return from the feed-in tariff scheme. However, the increase in irradiance coupled with the usage of a concentrator also increases the temperature of the PV cell, which will subsequently reduce the electrical performance $[39,75]$ and even may cause accelerated aging of the PV cell [76]. It is therefore crucial for any LCPV system to have the right RADTIRC design and cooling system to ensure that the performance of the solar cell is at its optimum. If an RADTIRC design with higher gain is needed, the solar cell could be cooled by introducing a hybrid/thermal system (either using air or water), that utilises the co-generated heat to produce hot water and stimulate ventilation $[30,38,77]$. 


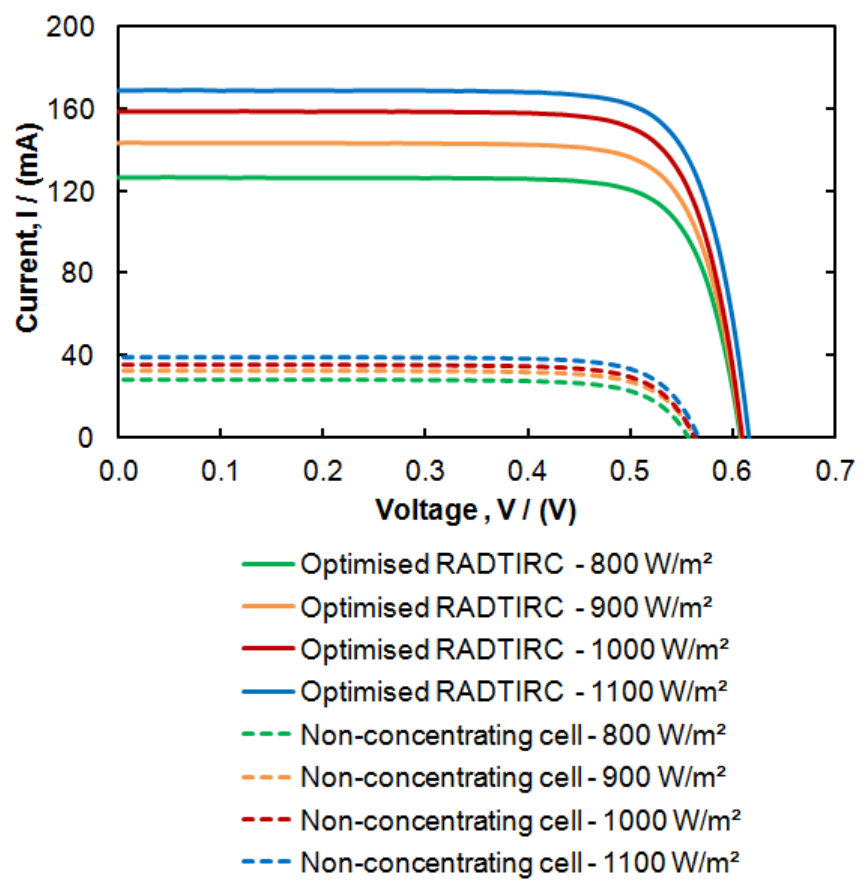

Figure 17: The I-V characteristic of the optimised RADTIRC-PV structure under various levels of irradiance.

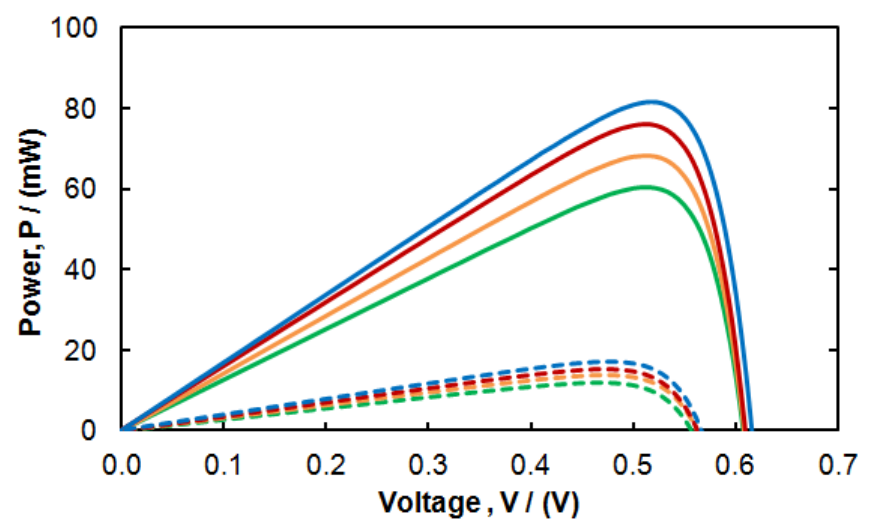

Optimised RADTIRC - $800 \mathrm{~W} / \mathrm{m}^{2}$

Optimised RADTIRC - $900 \mathrm{~W} / \mathrm{m}^{2}$

Optimised RADTIRC - $1000 \mathrm{~W} / \mathrm{m}^{2}$

Optimised RADTIRC - $1100 \mathrm{~W} / \mathrm{m}^{2}$

- - Non-concentrating cell $-800 \mathrm{~W} / \mathrm{m}^{2}$

- - Non-concentrating cell - $900 \mathrm{~W} / \mathrm{m}^{2}$

-- Non-concentrating cell - $1000 \mathrm{~W} / \mathrm{m}^{2}$

- - Non-concentrating cell - $1100 \mathrm{~W} / \mathrm{m}^{2}$

627 Figure 18: The P-V characteristic of the optimised RADTIRC-PV structure under various 


\section{Conclusions}

The aim of this paper is to carry out the first optimisation on the concentrator known as the RADTIRC developed by Ramirez-Iniguez et al. [37] at the GCU. Despite the first prototype yielding good results, two problems were identified: (i) the dimensions of the concentrator were smaller than the design specifications due to the usage of a silicon mould, and (ii) the material used in the prototype suffered a discoloration and photo degradation with time which reduced its maximum power performance by $7.84 \%$ after 2 years.

The criteria for choosing the most suitable material was presented and it was found that PMMA is one of the suitable materials to fabricate the concentrator - namely due to its excellence transmittance (92\%) and high resistance to photo degradation properties [40-42]. Afterwards, two different fabrication methods were discussed, i.e. injection moulding and SPDT. The former is chosen due to its cheaper cost to mass produce more concentrators (for future analysis) than the latter.

The performance of optimised prototype was analysed by using ZEMAX® and it was found that the optimised prototype was capable of producing a peak optical concentration gain of 4.62 and a maximum optical efficiency of $94.2 \%$ at normal incidence. To verify the simulation results, controlled indoor experimental work was carried out and the setup and the results obtained from the experiments were presented in detail. It was found that the optimised RADTIRC-PV structure generated an opto-electronic gain of 4.48 when compared with the bare cell under the STC. A comparison with the old prototype showed that the optimised RADTIRC-PV structure design increased the short circuit current by $13.57 \%$ under the STC. In terms of opto-electronic gain and optical efficiency, the results from the experiment showed good agreement with the simulation data, with a deviation of $3.5 \%$ at the peak value. This deviation can be attributed to several factors, which include (i) manufacturing errors causing the dimensions of the concentrator to differ from the actual design dimensions, uneven surfaces of the entrance aperture and over polishing on the profile of the side wall, and (ii) assembly errors during the soldering of the tabbing wire on the solar cells which reduced the effective area of each cell and misalignment between the solar cell and the exit aperture of the concentrator.

Based on these findings, some future work that could be investigated include: (i) creating a small solar window incorporating an array of these RADTIRC design and evaluate its long term performance under real conditions; (ii) analysis of the effect of diffuse radiation on the concentrator, and (iii) effect of the temperature on the performance of the concentrator. 
Acknowledgments

668

This project is funded by Glasgow Caledonian University (GCU), Scotland's Energy

Technology Partnership (ETP) and Majlis Amanah Rakyat (MARA), Malaysia. The authors

would like to acknowledge the collaboration of AES Ltd. and its contribution to this project.

Thanks are due to Mr Ian Baistow from Solar Capture Technologies Ltd, United Kingdom for

providing the solar cells, Mr Antoine Y Messiou from UK Optical Plastics Limited, United

Kingdom for fabricating the concentrators and Mr Mark Kragh from Off- Grid Europe,

Germany for supplying the tabbing wire.

678

679

680

681

682

683

684

685

686

687

688

689

690

691

692

693

694

695

696

697

698

699

\section{References}

[1] IPCC. Special Report on Renewable Energy Sources and Climate Change Mitigation. United Kingdom and New York, NY, USA: Cambridge University Press; 2011.

[2] IPCC. Climate Change 2014: Mitigation of Climate Change. Contribution of Working Group III to the Fifth Assessment Report of the Intergovernmental Panel on Climate Change. Cambridge University Press, Cambridge, United Kingdom and New York, NY, USA.: 2014.

[3] Pall P, Aina T, Stone DA, Stott PA, Nozawa T, Hilberts AGJ, et al. Anthropogenic greenhouse gas contribution to flood risk in England and Wales in autumn 2000. Nature 2011;470:382-5.

[4] Scialla M. Climate change blamed for severe drought hitting Vietnam's coffee crops. The Guardian UK 2015.

[5] Min S-K, Zhang X, Zwiers FW, Hegerl GC. Human contribution to more-intense precipitation extremes. Nature 2011;470:378-81.

[6] Dirks JA, Gorrissen WJ, Hathaway JH, Skorski DC, Scott MJ, Pulsipher TC, et al. Impacts of climate change on energy consumption and peak demand in buildings: A detailed regional approach. Energy 2015;79:20-32.

[7] Li DHW, Yang L, Lam JC. Impact of climate change on energy use in the built environment in different climate zones - A review. Energy 2012;42:103-12.

[8] Wan KKW, Li DHW, Lam JC. Assessment of climate change impact on building energy use and mitigation measures in subtropical climates. Energy 2011;36:1404-14.

[9] Luque A, Hegedus S. Handbook of Photovoltaic Science and Engineering, 2nd Edition. John Wiley and Sons, Ltd.; 2010. 
[10] REN21. Renewables 2015 Global Status Report. France: 2015.

[11] Li DHW, Yang L, Lam JC. Zero energy buildings and sustainable development implications - A review. Energy 2013;54:1-10.

[12] Fokaides PA, Christoforou EA, Kalogirou SA. Legislation driven scenarios based on recent construction advancements towards the achievement of nearly zero energy dwellings in the southern European country of Cyprus. Energy 2014;66:588-97.

[13] Ismail AM, Ramirez-Iniguez R, Asif M, Munir AB, Muhammad-Sukki F. Progress of solar photovoltaic in ASEAN countries: A review. Renewable and Sustainable Energy Reviews 2015;48:399-412.

[14] Muhammad-Sukki F, Abu-Bakar SH, Munir AB, Mohd Yasin SH, Ramirez-Iniguez R, McMeekin SG, et al. Feed-in tariff for solar photovoltaic: The rise of Japan. Renewable Energy 2014;68:636-43.

[15] Muhammad-Sukki F, Ramirez-Iniguez R, Munir AB, Mohd Yasin SH, Abu-Bakar SH, McMeekin SG, et al. Revised feed-in tariff for solar photovoltaic in the United Kingdom: A cloudy future ahead? Energy Policy 2013;52:832-8.

[16] Ahmad S, Tahar RM, Muhammad-Sukki F, Munir AB, Rahim RA. Role of feed-in tariff policy in promoting solar photovoltaic investments in Malaysia: A system dynamics approach. Energy 2015;84:808-15.

[17] Goodrich A, Hacke P, Wang Q, Sopori B, Margolis R, James TL, et al. A wafer-based monocrystalline silicon photovoltaics road map: Utilizing known technology improvement opportunities for further reductions in manufacturing costs. Solar Energy Materials and Solar Cells 2013;114:110-35.

[18] Sarmah N. Design and Performance Evaluation of a Low Concentrating Line-axis Dielectric Photovoltaic System. PhD Thesis, Heriot-Watt University, United Kingdom, 2012.

[19] Sellami N. Design and characterisation of a novel translucent solar concentrator. $\mathrm{PhD}$ Thesis, Heriot-Watt University, United Kingdom, 2013.

[20] Mallick TK. Optics and heat transfer for asymmetric compound parabolic photovoltaic concentrators for building integrated photovoltaics. PhD Thesis, University of Ulster, United Kingdom, 2003.

[21] Muhammad-Sukki F. Optimised solar concentrator for the solar photonic optoelectronic transformer system. PhD Thesis, Glasgow Caledonian University, United Kingdom, 2013.

[22] Muhammad-Sukki F, Ramirez-iniguez R, Mcmeekin SG, Stewart BG, Clive B. Solar Concentrators. International Journal of Applied Sciences 2010;1:1-15. 
[23] Sarmah N, Richards BS, Mallick TK. Design, development and indoor performance analysis of a low concentrating dielectric photovoltaic module. Solar Energy 2014;103:390-401.

[24] Sarmah N, Mallick TK. Design, fabrication and outdoor performance analysis of a low concentrating photovoltaic system. Solar Energy 2015;112:361-72.

[25] Mallick T, Eames P. Design and fabrication of low concentrating second generation PRIDE concentrator. Solar Energy Materials and Solar Cells 2007;91:597-608.

[26] Guiqiang L, Gang P, Yuehong S, Yunyun W, Jie J. Design and investigation of a novel lens-walled compound parabolic concentrator with air gap. Applied Energy 2014; $125: 21-7$.

[27] Li G, Pei G, Ji J, Su Y. Outdoor overall performance of a novel air-gap-lens-walled compound parabolic concentrator (ALCPC) incorporated with photovoltaic/thermal system. Applied Energy 2015;144:214-23.

[28] Guiqiang L, Gang P, Yuehong S, Jie J, Riffat SB. Experiment and simulation study on the flux distribution of lens-walled compound parabolic concentrator compared with mirror compound parabolic concentrator. Energy 2013;58:398-403.

[29] Li G, Pei G, Yang M, Ji J, Su Y. Optical evaluation of a novel static incorporated compound parabolic concentrator with photovoltaic/thermal system and preliminary experiment. Energy Conversion and Management 2014;85:204-11.

[30] Muhammad-Sukki F, Ramirez-Iniguez R, McMeekin S, Stewart B, Clive B. Optimised Dielectric Totally Internally Reflecting Concentrator for the Solar Photonic Optoelectronic Transformer System: Maximum Concentration Method. In: Setchi R, Jordanov I, Howlett R, Jain L, editors. Knowledge-Based and Intelligent Information and Engineering Systems SE - 67, vol. 6279, Springer Berlin Heidelberg; 2010, p. $633-41$.

[31] Muhammad-Sukki F, Ramirez-iniguez R, McMeekin SG, Stewart BG, Clive B. Optimised concentrator for the Solar Photonic Optoelectronic Transformer System : First optimisation stage. International Conference on Harnessing Technology (ICHT), Muscat, Oman: 2011, p. 1-7.

[32] Muhammad-Sukki F, Ramirez-iniguez R, McMeekin SG, Stewart BG, Clive B. Optimised concentrator for the Solar Photonic Optoelectronic Transformer System : First optimisation stage. Caledonian Journal of Engineering 2011;07:19-24.

[33] Muhammad-Sukki F, Ramirez-Iniguez R, McMeekin SG, Stewart BG, Clive B. Optimisation of concentrator in the solar photonic optoelectronic transformer: optical gain analysis. IET Conference on Renewable Power Generation (RPG 2011), IET; 2011, p. P04 1-6.

[34] Muhammad-Sukki F, Ramirez-Iniguez R, McMeekin SG, Stewart BG, Clive B. Optimisation of Concentrator in the Solar Photonic Optoelectronic Transformer : Comparison of Geometrical Performance and Cost of Implementation. International 
Conference on Renewable Energies and Power Quality (ICREPQ'11), Las Palmas de Gran Canaria, Spain: 2011, p. 1-6.

[35] Muhammad-Sukki F, Ramirez-Iniguez R, McMeekin SG, Stewart BG, Clive B. Optimisation of Concentrator in the Solar Photonic Optoelectronic Transformer : Comparison of Geometrical Performance and Cost of Implementation. Renewable Energy and Power Quality Journal 2011;9:1-6.

[36] Muhammad-Sukki F, Ramirez-iniguez R, McMeekin SG, Stewart BG, Clive B. Solar concentrators in malaysia: Towards the development of low cost solar photovoltaic systems. Jurnal Teknologi 2011;54:289-98.

[37] Ramirez-iniguez R, Muhammad-Sukki F, McMeekin SG, Stewart BG. Optical element. Patent No. 2497942, 2014.

[38] Muhammad-Sukki F, Abu-bakar SH, Ramirez-iniguez R, McMeekin SG, Stewart BG, Sarmah N, et al. Mirror symmetrical dielectric totally internally reflecting concentrator for building integrated photovoltaic systems. Applied Energy 2014;113:32-40.

[39] Muhammad-Sukki F, Abu-Bakar SH, Ramirez-Iniguez R, McMeekin SG, Stewart BG, Munir AB, et al. Performance analysis of a mirror symmetrical dielectric totally internally reflecting concentrator for building integrated photovoltaic systems. Applied Energy 2013;111:288-99.

[40] Boedeker Plastics Inc. 2015. Acrylic PMMA (Polymethyl-Methacrylate) Specifications. Available from http://www.boedeker.com/acryl_p.htm. Last accessed on $01 / 03 / 2015$.

[41] Rainhart LG, Schimmel WP. Effect of outdoor aging on acrylic sheet. Solar Energy $1975 ; 17: 259-64$.

[42] Woodman JF. Acrylics. Modern Plastics Encyclopedia 1971;14.

[43] Xie WT, Dai YJ, Wang RZ, Sumathy K. Concentrated solar energy applications using Fresnel lenses: A review. Renewable and Sustainable Energy Reviews 2011;15:2588606.

[44] Kuo C-FJ, Huang C-C, Kuo Y-L. Analysis of processing parameters in fabrication of Fresnel lens solar collector. Energy Conversion and Management 2012;57:33-41.

[45] Hornung T, Steiner M, Nitz P. Estimation of the influence of Fresnel lens temperature on energy generation of a concentrator photovoltaic system. Solar Energy Materials and Solar Cells 2012;99:333-8.

[46] Pei G, Li G, Su Y, Ji J, Riffat S, Zheng H. Preliminary Ray Tracing and Experimental Study on the Effect of Mirror Coating on the Optical Efficiency of a Solid Dielectric Compound Parabolic Concentrator. Energies 2012;5:3627-39. 
[47] Sarmah N, Richards BS, Mallick TK. Evaluation and optimization of the optical performance of low-concentrating dielectric compound parabolic concentrator using ray-tracing methods. Applied Optics 2011;50:3303-10.

[48] Reda SM. Stability and photodegradation of phthalocyanines and hematoporphyrin doped PMMA as solar concentrators. Solar Energy 2007;81:755-60.

[49] Pandey KK, Pant TC. Solar energy concentrator based on uranyl-doped PMMA. Solar Energy Materials 1991;21:327-34.

[50] El-Bashir SM. Photophysical properties of fluorescent PMMA/SiO2 nanohybrids for solar energy applications. Journal of Luminescence 2012;132:1786-91.

[51] Kocher-Oberlehner G, Bardosova M, Pemble M, Richards BS. Planar photonic solar concentrators for building-integrated photovoltaics. Solar Energy Materials and Solar Cells 2012;104:53-7.

[52] Stratasys Ltd. 2015. Materials. Available from http://www.stratasys.com/materials. Last accessed on 01/03/ 2015.

[53] BPF. 2014. Injection Moulding. Available from http://www.bpf.co.uk/plastipedia/processes/Injection_Moulding.aspx. Last accessed on 03/03/ 2015.

[54] BBC. 2014. Materials. Available from http://www.bbc.co.uk/schools/gcsebitesize/design/resistantmaterials/materialsmaterials rev3.shtml. Last accessed on 03/03/ 2015.

[55] Zhuang Z, Yu F. Optimization design of hybrid Fresnel-based concentrator for generating uniformity irradiance with the broad solar spectrum. Optics \& Laser Technology 2014;60:27-33.

[56] Languy F, Lenaerts C, Loicq J, Thibert T, Habraken S. Performance of solar concentrator made of an achromatic Fresnel doublet measured with a continuous solar simulator and comparison with a singlet. Solar Energy Materials and Solar Cells 2013;109:70-6.

[57] Rutland Plastics Limited. 2015. Plastic Injection Moulding Machine. Available from http://www.rutlandplastics.co.uk/advice/moulding_machine.html. Last accessed on 03/03/ 2015.

[58] NanoPlas Inc. 2014. 5 Major Advantages to Using Plastic Injection Molding for the Manufacturing of Parts. Available from http://nanomoldcoating.com/5-majoradvantages-to-using-plastic-injection-molding-for-the-manufacturing-of-parts/. Last accessed on $03 / 03 / 2015$.

[59] AV Plastics. 2015. About Injection Moulding. Available from http://www.avplastics.co.uk/advantages-and-disadvantages-of-injection-moulding. Last accessed on 03/03/ 2015. 
[60] Rhorer RL, Evans CJ. Fabrication of optics by diamond turning. In: Bass M, editor. Handbook of Optics: Volume II - Design, Fabrication, and Testing; Sources and Detectors; Radiometry and Photometry, McGraw Hill Professional, Access Engineering; 2010, p. 41.1-41.13.

[61] Nalux Nano Optical. 2015. Diamond turning. Available from http://www.naluxnanooptical.com/Diamond_Turning.html. Last accessed on 13/2/ 2015.

[62] Karp JH, Ford J. Multiband solar concentrator using transmissive dichroic beamsplitting. Proceedings of SPIE 7043, San Diego, CA; United States: The International Society for Optical Engineering; 2008.

[63] Allsop JL, Mateboer A, Shore P. Optimising efficiency in diamond turned Fresnel mould masters. In: Ambs P, Curticapean D, Emmelmann C, Knapp W, Kuznicki ZT, Meyrueis PP, editors. SPIE Eco-Photonics, International Society for Optics and Photonics; 2011, p. 806509-806509- 11.

[64] Fang FZ, Zhang XD, Weckenmann A, Zhang GX, Evans C. Manufacturing and measurement of freeform optics. CIRP Annals - Manufacturing Technology 2013;62:823-46.

[65] Messiou A. Y. UK Optical Plastics Ltd. Available from Http://www.ukopticalplastics.com/index.html - Accessed 10 Nov 2014.

[66] Huang C. Investigation of injection molding process for high precision polymer lens manufacturing. The Ohio State University, 2008.

[67] ARKEMA GROUP. Standard range - Altuglas ${ }^{\circledR}$ acrylic resins. Available from Http://www.altuglas.com/en/resins/resins-by-Performance/standard-Range/index.html - Accessed 10 Nov 2014.

[68] Solar Capture Technologies. Cells. Available from Http://solarcapturetechnologies.com/services/manufacturing/cells - Accessed 10 Nov 2014.

[69] Kempe MD. Accelerated UV test methods and selection criteria for encapsulants of photovoltaic modules. 2008 33rd IEEE Photovolatic Specialists Conference, IEEE; 2008, p. 1-6.

[70] Sellami N, Mallick TK, McNeil DA. Optical characterisation of 3-D static solar concentrator. Energy Conversion and Management 2012;64:579-86.

[71] Welford WT, Winston R. High Collection Nonimaging Optics. Academic Press; 1989.

[72] Stine WB, Geyer M. Power from the Sun. Availabe from http://www.powerfromthesun.net/Book/chapter02/chapter02.html- Accessed 10 June 2014. 
[73] Ning X, Winston R, O'Gallagher J. Dielectric totally internally reflecting concentrators. Applied Optics 1987;26:300-5.

[74] Mammo ED, Sellami N, Mallick TK. Performance analysis of a reflective 3D crossed compound parabolic concentrating photovoltaic system for building façade integration. Progress in Photovoltaics: Research and Applications 2013;21:1095-103.

[75] Abu-Bakar SH, Muhammad-Sukki F, Freier D, Ramirez-Iniguez R, Mallick TK, Munir AB, et al. Performance analysis of a novel rotationally asymmetrical compound parabolic concentrator. Applied Energy 2015;154:221-31.

[76] Núñez N, González JR, Vázquez M, Algora C, Espinet P. Evaluation of the reliability of high concentrator GaAs solar cells by means of temperature accelerated aging tests. Progress in Photovoltaics: Research and Applications 2013;21:1104-13.

[77] Kumar R, Rosen MA. A critical review of photovoltaic-thermal solar collectors for air heating. Applied Energy 2011;88:3603-14. 